phenylalanine, bind strongly to human serum proteins in vitro and are displaced by all the commonly used antirheumatic drugs (McArthur et al., 1971). In addition, there should be some difference in the degree of binding of such "protective" peptides to normal serum proteins and to the proteins in serum of patients with rheumatoid arthritis. It has been reported (Denko et al., 1970) that in patients with the rheumatic diseases the circulating albumin possesses an abnormal amino-acid composition, and this would be expected to be associated with different binding affinities and capacities for small molecules compared with normal serum albumin.

It is therefore proposed that the clinically useful drugs used in the treatment of rheumatoid arthritis and the other rheumatic diseases act by displacing peptides from their binding sites to serum proteins. The free form of the peptides protects connective tissues from the effects of inflammatory insults. In the rheumatic diseases there is a relative deficiency in the concentrations of free protective peptides in the circulation.

In the present paper preliminary experimental results supporting this hypothesis are presented. There remain certain critical experiments which need to be performed. It must be shown that the drugs displace peptides from their binding to the plasma proteins of normal subjects and of patients with rheumatoid arthritis and similar diseases. The displaced peptides must be separated and identified. There should be differences between the free concentrations of some of these peptides in normal subjects and in patients with rheumatic diseases who have not received therapy with any of the antirheumatic drugs. Finally, among the peptides displaced by the drugs should be one or more compounds which exert a protective action against chronic inflammatory stimuli.

There are several important implications of the above hypothesis. If the role of peptides, in their free forms, is established and if they can be identified then a more direct form of therapy in the rheumatic diseases becomes available. Chemical synthesis could provide a large range of useful compounds. Early diagnosis of rheumatoid conditions could be facilitated by measuring the free concentrations either of these peptides or of other molecules which are displaced to a similar extent by the currently used drugs. More efficient control of therapy could be assessed by serial measurements of free fractions of the peptides. The screening of potential anti-inflammatory substances would be placed on a more rational basis if activity were related to ability to displace peptides from circulating proteins.

We wish to thank Sir Edward Muir, Mr. L. T. Cotton, Mr. J. L. Dawson, Mr. J. M. Brudenell, and Dr. Roger Williams for allowing us to study patients under their care, and the King's College Hospital and Medical School Research Committee for financial support.

\section{References}

Collier, H. O. J. (1969). Nature, 223, 35.

Davis, R. H., Fisher, J. S., and McGowan, L. (1968). Journal of Endocrinology, 41, 603

Dawkins, P. D., and Smith, M. J. H. (1971). Fournal of Pharmacy and Pharmacology, In press.

Denko, C. W., Purser, O. B., and Johnson, R. M. (1970). Arthritis and Rheumatism, 13, 311.

Goldstein, A. (1949). Pharmacological Reviews, 1, 102

Hench, P. S. (1949). Annals of the Rheumatic Diseases, 8,90

Hess, S. M., and Udenfriend, S. (1959). Fournal of Pharmacology and Experimental Therapeutics, $127,175$.

McArthur, J. N., and Dawkins, P. D. (1969). Fournal of Pharmacy and Pharmacology, 21, 744.

McArthur, J. N., Dawkins, P. D., and Smith, M. J. H. (1971). Fournal of Pharmacy and Pharmacology. 23, 393

McMenamy, R. H., and Oncley, J. L. (1958). Fournal of Biological Chemistry, 233, 1436. Ropes, M. W., Bennett, G. A., Cobb, S., Jacox, R., and Jessar, R. A. (1959).
Annals of the Rheumatic Diseases, 18, 49.

Rubin, A. L., Lubash, G. D., Aronson, R. F., and Davison, P. F. (1963). Nature, 197, 1009 .

Skidmore, I. F., and Trnavsky, K. (1967). Some Aspects of Anti-Inflammatory Drugs. Prague, Rapid, Foreign Trade Publicity Corporation. Spector, W. G., and Willoughby, D. A. (1968). The Pharmacology of In-
flammation. London, English Universities Press.

Smith, H. G., and Lakatos, C. (1971). Fournal of Pharmacy and Pharma-

cology, 23, 180.
Smith, M. J. H. (1966). The Salicylates. New York, Interscience.

Whitehouse, M. W. (1965). Progress in Drug Research, 8, 321.

\title{
Thyrotoxicosis in the African: Clinical and Immunological Observations
}

\author{
P. E. MCGILL
}

\section{Introduction}

Thyrotoxicosis is considered to be rare among the indigenous populations of Africa. During the past decade about 50 cases were recorded in the world literature. Trowell (1960) saw two African patients with thyrotoxicosis in 30 years of medical practice in East Africa. Gelfand (1962) reported the first Rhodesian African patient in whom he was certain of the diagnosis. Thyrotoxicosis is rare among the indigenous populations of South Africa (Dancaster, 1970), Uganda (Patel, 1962), and Nigeria (Taylor, 1968). In Kenya thyrotoxicosis was thought to be extremely rare until Wright (1967) described eight cases. Taylor (1968) and Dancaster (1970) suggested that the rarity of thyrotoxicosis in the African is an immunological phenomenon related to an inability of the African to produce autoimmune antibodies. This problem has not been adequately studied because of the small numbers of patients encountered by each observer, and the total lack of data on autoantibody formation in African thyrotoxic patients.

This paper is a report of 25 African patients with thyrotoxicosis in whom thyroid autoantibodies have been measured.

\footnotetext{
Postgraduate Medical Institute, Royal Devon and Exeter Hospital, Exeter

P. E. McGILI, M.B., M.R.C.P.ED., Senior Research Registrar (Formerly Lecturer in Medicine, University College, Nairobi, Kenya)
} 
In addition, the thyroid glands of 30 Africans with thyrotoxicosis and 30 appropriately matched Caucasians have been assessed for the histological features of autoimmune thyroid disease (lymphocyte and plasma cell infiltration).

\section{Patients}

All African patients were investigated and treated at the Kenyatta National Hospital, Nairobi, between April 1968 and April 1970. The diagnosis was established in all patients with the "clinical diagnostic index" described by Crooks et al. (1959) and by the clinical response to antithyroid drugs. Confirmation of the diagnosis was obtained in 23 patients by estimation of the serum protein-bound iodine (P.B.I.). The characteristic histological appearances of toxic diffuse goitre (Graves's disease) confirmed the clinical diagnosis in two patients in whom the P.B.I. was not estimated. Additional investigations in eight patients included the measurement of the four-hour and 48-hour thyroid gland uptake of radioiodine (Wayne, 1960). The sex and age of each patient was noted (in about one-third of patients the age was not known; in these cases the age was "assessed"). Goitre consistency (diffuse or nodular) was assessed by palpation and its duration recorded. The presence of ocular signs was noted, the criteria described by Crooks et al. (1959) being used.

There were 20 female and five male patients whose ages ranged from 8 to 60 years. Most were aged between 25 and 45 . Twenty ( 15 female and 5 male) were considered to have Graves's disease (toxic diffuse goitre) on the basis of having a diffuse goitre of recent onset ( $<2$ years). Unequivocal exophthalmos was present in six female and four male patients with toxic diffuse goitre. One female patient had pretibial myxoedema and exophthalmos.

Four female patients had a long-standing ( $>5$ years) multinodular goitre; all were over 50 years of age, and two presented with cardiac failure resistant to therapy with digoxin and diuretics. One elderly man who had a solitary thyroid adenoma ("hot" nodule) developed atrial fibrillation and sustained a fatal cerebral embolism. After courses of antithyroid drug therapy, lasting between 3 and 12 months, subtotal thyroidectomy was performed in 10 patients.

\section{Studies}

Immunological Studies.-Serum was obtained from all patients before and during treatment with antithyroid drugs. In Nairobi all sera were tested for antibody to thyroglobulin by a tanned red blood cell haemagglutination method, Burroughs Wellcome reagents and a microtitre apparatus (Goldin et al., 1965) being used. The sera were frozen and sent by air to the Department of Pathology, Western Infirmary, Glasgow, and tested for antibody to thyroglobulin (Fulthorpe et al., 1961) and antibody to thyroid microsomes (Holborow et al., 1959).

Histological Studies.-Thyroid tissue was available for study from 10 patients in this series who had undergone subtotal thyroidectomy and from 20 African thyrotoxic patients similarly treated at the Kenyatta National Hospital, Nairobi, between 1963 and 1967. Sections of thyroid tissue from 30 Caucasian thyrotoxic patients were obtained from the department of pathology, Royal Devon and Exeter Hospital, Exeter, Devon. The patients were matched with the above African group for sex, and as closely as possible for age, duration of antithyroid drug therapy before surgery, exophthalmos, and consistency of goitr 2 . Round-cell infiltration was assessed in all cases by counting the number of low-power fields containing round-cell aggregates out of 50 fields for each gland (Buchanan et al. 1962).

\section{Results}

Antibody to thyroglobulin was detected in the serum of one patient and antibody to thyroid microsomes in the serum of four patients. In two patients with "microsomal" antibody no roundcell infiltration was present in postoperative thyroid gland sections. Round-cell infiltration was present in the thyroid gland sections of $22(73 \%)$ Caucasian patients and in $8(27 \%)$ African patients (see Chart).

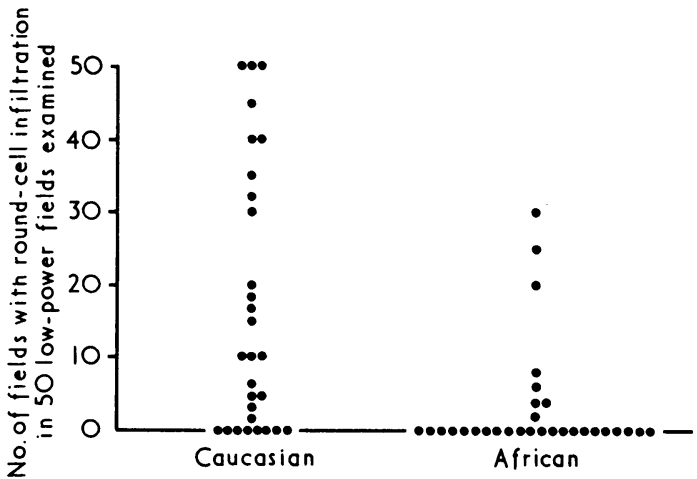

Round-cell infiltration of the thyroid gland in 30 Caucasian and 30 African thyrotoxic subjects.

\section{Discussion}

In no patient was the diagnosis in doubt. Thyrotoxicosis was associated with a diffuse goitre in 20 patients and a nodular goitre in five. Exophthalmos was present in $50 \%$ of patients with toxic diffuse goitre and was accompanied by pretibial myxoedema in one patient. Thyrocardiac disease (congestive cardiac failure, atrial fibrillation) occurred only in elderly patients with toxic nodular goitre. No unusual symptoms or signs were recorded. Thus in the African the clinical manifestations of thyrotoxicosis are similar to those observed in other races.

In Durban, Natal, thyrotoxicosis is $\mathbf{3 0}$ times more common in the Indian and Caucasian populations than in the Bantu (Dancaster, 1970), and in Southern Rhodesia it is confined almost exclusively to the Caucasian race (Shee and Houston, 1963). Though the experience of 25 patients within two years represents a considerably increased incidence over the reported incidence from elsewhere in Africa, it is clear that thyrotoxicosis is still an uncommon disease among the indigenous populations of Kenya.

Reasons for the racial differences in the incidence of thyrotoxicosis must be related to the pathogenesis which, though not completely clarified, seems to be related to a disturbance of immune tolerance. The presence of thyroid autoantibodies and round-cell infiltration of the thyroid gland in a high proportion of Caucasian thyrotoxic patients and the close clinical and immunological associations between thyrotoxicosis and other autoimmune diseases indicate that autoimmunization plays an important part in the aetiology of thyrotoxicosis (Anderson et al., 1964). In addition, the abnormal thyroid stimulator (long-acting thyroid stimulator) found in the serum of a high proportion of patients with Graves's disease may be an autoantibody to the thyroid (McKenzie, 1967).

In the present study the incidence of thyroid round-cell infiltration in the Caucasian group was similar to the incidence reported by other workers (Roitt and Doniach, 1960; Buchanan et al., 1962). The incidence and degree of thyroid round-cell infiltration was significantly lower in the African group than in the Caucasian group. Circulating thyroid autoantibodies were detected in $16 \%$ of African patients, in contrast to the reported 
incidence of between 40 and $70 \%$ in series of Caucasian thyrotoxic patients (Roitt and Doniach, 1960; Bastenie et al., 1967).

These studies indicate that the predisposition to form thyroid autoantibodies is weak in the African thyrotoxic patient. In this context it is worth noting that all varieties of autoimmune disease are considered to be uncommon or rare among indigenous African populations (Greenwood, 1968) and autoimmune thyroiditis (spontaneous myxoedema and Hashimoto's thyroiditis) seems to be extremely rare. For example, in Kenya 600 consecutive thyroidectomy specimens from African patients were studied for round-cell infiltration and in one case the histological features of Hashimoto's disease were observed; 520 African patients with a variety of thyroid disorders were reviewed by observers experienced in thyroid disease over a two-year period (with access to P.B.I. estimations and with facilities for the estimation of antithyroglobulin and performing radioiodine tests) and no cases of spontaneous myxoedema or Hashimoto's disease were detected (McGill, unpublished data). Clearly the immunological system of the indigenous African is at present either resistant to or is not exposed to antigenic stimuli which initiate and maintain autoantibody formation. Further study of the apparently unique immunological mechanism of the indigenous African is indicated.

I wish to thank Professor A. D. Roy and Mr. G Neville for assistance in the management of many of the patients; Professor R. B. Goudie for antibody studies; Dr. W. D. Alexander for P.B.I. estimations; Professor H. M. Cameron for access to pathology archives in Nairobi and Dr. R. A. Caldwell in Exeter. Professor W. F. M. Fulton gave encouragement throughout this study, which was supported by a grant from University College, Nairobi.

\section{References}

Anderson, J. R., Gray, K. G., Middleton, D. G., and Young, J. A. (1964). British Medical fournal, 2, 1630.

Bastenie, P. A., Bonnyns, M., and Vanhaelst, L. (1967). In Thyrotoxicosis, ed. W. J. Irvine, p. 40. Edinburgh, Livingstone.

Buchanan, W. W., et al. (1962). Fournal of Endocrinology, 24, 115

Crooks, J., Murray, I. P. C., and Wayne, E. J. (1959). Quarterly fournal of Medicine, 28, 211.

Dancaster, C. P. (1970). South African Medical Fournal, 44, 695.

Fulthorpe, A. J., Roitt, I. M., Doniach, D., and Couchman, K. (1961). fournal of Clinical Pathology, 14, 654 .

Gelfand, M. (1962). Central African fournal of Medicine, 8, 123.

Goldin, M., Rosenblum, L., and Black, A. (1965). American fournal of Clinical Pathology, 43, 555.

Greenwood, B. M. (1968). Lancet, 2, 380.

Holborow, E. J., Brown, P. C., Roitt, I. M., and Doniach, D. (1959). British fournal of Experimental Pathology, 40, 583.

McKenzie, J. M. (1967). In Thyrotoxicosis, ed. W. J. Irvine, p. 12. Edinburgh, Livingstone.

Patel, K. M. (1962). East African Medical fournal, 39, 600.

Roitt, I. M., and Doniach, D. (1960). British Medical Bulletin, 16, 152.

Schade, R. O. K., Owen, S. G., Smart, G. A., and Hall, R. (1960). Fournal of Clinical Pathology, 13, 499.

Shee, J. C., and Houston, W. (1963). Central African Fournal of Medicine, 9. 267

Taylor, J. R. (1968). East African Medical Yournal, 45, 390.

Trowell, H. C. (1960). In Non-Infective Disease in Africa, p. 286. London, Edward Arnold.

Wayne, E. J. (1960). British Medical fournal, 1, 1,78.

Wright, C. J. (1967). East African Medical fournal, 44, 455.

\section{Summary}

Massive pulmonary embolism was confirmed by pulmonary arteriography in 23 patients. All were seen between 2 and 48 hours after the onset of embolism and none had pre-existing cardiorespiratory disease. Fifteen were treated with streptokinase and eight with heparin. Factors which might influence prognosis and rate of resolution were similar in the patients in each group, and there was no significant difference between the groups in terms of pretreatment haemodynamic or arteriographic findings. Haemodynamic and arteriographic findings after treatment for 72 hours provided an objective measurement of resolution, which was significantly greater in the streptokinase-treated patients.

-This study forms part of an M.D. thesis submitted to the University of Cambridge by one of us (G. C. S.).

Brompton Hospital, London S.W.3

G. A. H. MILLER, D.M., M.R.C.P., Director, Cardiac Laboratory

G. A. H. MILLER, D.M., M.R.C.P., Director, Cardiac Labora

G. C. SUTTON, M.R.C.P., Senior Registrar in Cardiology

I. H. KERR, M.R.C.P., F.F.R., Consultant in Diagnostic R

R. V. GIBSON, F.R.C.P., Physician, Cardiac Departme
MONEY, F.R.C.P., Physician, Cardiac Department
There was no mortality in either group, but treatment had to be changed in two heparin-treated patients because of clinical deterioration. The principal complication of treatment, seen more often in the streptokinasetreated patients, was bleeding from cut-down or operation sites.

\section{Introduction}

This report is concerned with only one aspect of massive pulmonary embolism-namely, the rate of resolution in a selected series of patients after 72 hours' treatment with either heparin or streptokinase. The late results of treatment will be the subject of another report.

In comparing the effects of two different treatments on the natural history of pulmonary embolism certain conditions must be fulfilled. Firstly, patients in each group must be comparable, and, secondly, objective criteria for diagnosis and for assessment must be available. Among factors which may make comparisons difficult are (1) the severity of the embolism, (2) the duration of embolism, and (3) coexisting cardiorespiratory disease. Our 23 patients were similar in that all were shown by pulmonary arteriography to have massive pulmonary embolism of about equal severity, none had a history of more than $\mathbf{4 8}$ hours or less than two hours, and none had coexisting cardiorespiratory disease. Additionally, haemodynamic and arteriographic data were available before and after treatment to provide an objective assessment of the response to therapy. 